\title{
Host restriction factor SAMHD1 limits human T-cell leukemia virus (HTLV-1) infection of primary monocytes via the innate immune sensor STING
}

\author{
Alexandre Sze ${ }^{1}$, S Mehdi Belgnaoui ${ }^{1}$, Rongtuan Lin ${ }^{1}$, Julien van Grevenynghe ${ }^{1,2}$, John Hiscott ${ }^{2 *}$ \\ From 16th International Conference on Human Retroviruses: HTLV and Related Viruses \\ Montreal, Canada. 26-30 June 2013
}

Human T-lymphotropic virus type 1 (HTLV-1) is the causative agent of adult $\mathrm{T}$ cell leukemia (ATL) and other HTLV-1 associated neurological disorders. Unlike most retroviruses, cell-free HTLV-1 virions are poorly infectious and do not stably infect its primary CD4+ T lymphocyte target. However, HTLV-1 efficiently infects cells of the myeloid lineage, leading to productive infection of myeloid cells. Here, we investigate the mechanisms underlying monocyte infection by HTLV-1 and demonstrate that HTLV-1 infection induced apoptosis of monocytes in a SAMHD1-dependent manner. SAMHD1, a deoxynucleoside triphosphate triphosphohydrolase, functions as a restriction factor that limits HIV-1 replication by reducing the availability of deoxynucleosidetriphosphates (dNTPs) required for reverse transcription. RNAi-mediated silencing of SAMHD1 inhibited monocyte apoptosis, while addition of exogenous dNTPs, or pre-treatment with azidothymidine (AZT) to block reverse transcription also inhibited apoptosis. To investigate a role for reverse transcription intermediates (RTI) in triggering apoptosis, a biotinylated 90 nucleotide RTI from the U5 region of HTLV-1 was introduced into monocytes; strikingly, the biotinylated RTI induced apoptosis and bound to the DNA sensor STING - which mediates the antiviral response via IRF3 activation. We further demonstrated that STINGmediated apoptosis in infected monocytes required the generation of a pro-apoptotic complex between IRF3 and the Bcl-2 protein Bax. These studies provide a mechanistic explanation for HTLV-1 abortive infection of monocytes and report a link between SAMHD1 restriction of reverse transcription, sensing of retroviral reverse transcription

\footnotetext{
* Correspondence: hiscott@vgtifl.org

${ }^{2}$ Vaccine and Gene Therapy Institute of Florida, Port St. Lucie, FL, USA
}

Full list of author information is available at the end of the article intermediates by STING, and the initiation of IRF3-Bax driven apoptosis.

\section{Authors' details}

'Lady Davis Institute-Jewish General Hospital, McGill University, Montreal, Quebec, Canada. ${ }^{2}$ Vaccine and Gene Therapy Institute of Florida, Port St. Lucie, FL, USA.

Published: 7 January 2014

\section{doi:10.1186/1742-4690-11-S1-019}

Cite this article as: Sze et al: Host restriction factor SAMHD1 limits

human T-cell leukemia virus (HTLV-1) infection of primary monocytes via the innate immune sensor STING. Retrovirology 2014 11(Suppl 1):019.
Submit your next manuscript to BioMed Central and take full advantage of:

- Convenient online submission

- Thorough peer review

- No space constraints or color figure charges

- Immediate publication on acceptance

- Inclusion in PubMed, CAS, Scopus and Google Scholar

- Research which is freely available for redistribution

Submit your manuscript at www.biomedcentral.com/submit
() Biomed Central 